\title{
Productive and reproductive performance of Holstein Friesian crossbred and indigenous cow under small holder farming system
}

\author{
MJ A Mamun, MAS Khan*, MAH Sarker, MN I slam
}

Department of Dairy Science, Bangladesh Agricultural University, Mymensingh 2202, Bangladesh

\begin{abstract}
This study was done to investigate the productive and reproductive performances of Holstein Friesian crossbred (HF) and indigenous (IG) cows. A total 131 dairy cows of two genetic groups as IG (117 heads) and HF (14 heads) were selected randomly. The study found that the average milk yield per day of $\mathrm{HF}$ and IG cows were $7.64 \pm 1.74$ and $1.75 \pm 0.07$ liters/day, respectively. The milk yield was found significantly $(p<0.01)$ higher in HF cows than of IG cows. The lactation period of HF was significantly $(p<0.05)$ higher than of IG cows. Age at first calving of IG cows was significantly $(p<0.01) 4$ months higher than HF cows. The number of service per conception was almost similar for HF and IG cows. Higher significant difference was found in Post-partum oestrus $(p<0.05)$, dry period $(p<0.01)$, calving intervals $(p<0.01)$ of IG than HF cows. The gestation length of HF and IG cows was significantly indifferent. Above biological studies mentioned better productive and reproductive performance of $\mathrm{HF}$ cows than IG cows.
\end{abstract}

Key words: Indigenous cows, Holstein Friesian crossbred cows, Productive, Reproductive performance

Bangladesh Animal Husbandry Association. All rights reserved. Bang. J. Anim. Sci. 2015. 44(3): 166-170

\section{Introduction}

Bangladesh is an agro-based developing country where the two main challenges are elimination of the poverty and malnutrition. To overcome these challenges, livestock, mainly dairy cattle has been supporting much. Total cattle population in Bangladesh is about 24 million and total milk yield is 3518800 tons (FAOSTAT, 2013). According to Bangladesh economic survey (20132014), livestock sub-sector contributes about $1.84 \%$ of total GDP. According to Bangladesh economic survey (2013-2014), annual milk production is about 3.74 million tons. It is very low than the demand of 13.50 million tons in Bangladesh (DLS, 2014). Majority of the cattle population in Bangladesh is non-descript types, which do not conform to any particular breed and termed as indigenous cattle. They are smaller in size and their milk yield competence is lower than that of any exotic breeds of this kind. In our country, broadly there are two types of dairy cattle available, namely indigenous and crossbreds. The average production per day of indigenous and crossbred cows is $1.5 \mathrm{~L}$ and $2.5 \mathrm{~L}$

*Corresponding author: maskhands@gmail.com respectively (Saadullah, 2001). On the other hand, Islam et al. (2014) found that the milk production of $\mathrm{HF}$ Crossbred cows ranges from 2.5-8.5 $\mathrm{L}$ and which was 2.5-5.8 L in IG cows. Biologicaly potential for milk production depends on the age at puberty, early first calving, number of parity and shorter calving interval and milk yield. However, the intensity of production traits differs according to the genotype of breeds and parities (Djemali and Freeman, 1987; Rahman et al., 1987). The productive and reproductive performance in dairy cows at both subsistence and semi-intensive or intensive farming system had been subjected to several studies in Bangladesh (Alam and Ghosh, 1988; Ghosh et al., 1988; Shamsuddin et al., 1987) where delayed puberty, long post partum intervals with or without gynecological disorders had been envisaged. The crossbred cows are capable to produce higher quantity of milk but reported to be susceptible to diseases and their maintenance cost is also higher. Knowing these all things, a lot of people in rural, urban and peri-urban areas are interested to rear milking animals and in some cases, for starting small scale dairy farms. New 
Mamun el al. (2015) Bang. J. Amin. Sci. 44(3): 166- 170

breeds can be developed through selection, crossbreeding and upgrading for better production and profit. Although cattle population size in our country is satisfactory but their productivity is very low when compared with exotic dairy animals. Moreover, management practices vary from areas to areas, which have profound effects on dairy production. A large number of HF crossbreds and indigenous dairy cows are reared in the selective study area and there is no study has done as far as we are aware. Moreover, the area is well communicated and the farmers are responsive with the research work. The present study was therefore undertaken to investigate the productive and reproductive performances of $\mathrm{HF}$ crossbred and IG cows in Uzankashiar Char Village, Mymensingh.

\section{Materials and Methods}

This study was conducted at Uzankashiar Char Village, Mymensingh, for the period of six months from January to June 2014. A total 131 dairy cows of two genetic groups as IG (117 heads) and HF (14 heads) were selected randomly. The questionnaire was developed in accordance with the objectives of the study and designed in a simple manner to get accurate information. Each respondent was given a brief description about the nature and purpose of the study. The questions were asked in easy way with explanation where necessary and the responses were recorded directly on the survey schedule. The farmers followed the traditional management system for rearing the cows. The cows, which have at least three lactation periods, were only used for this study. The basal diet was rice straw with 3 to 4 hours grazing in a day. Concentrates (rice polish, common salt.) were also supplied once a day. The parameters envisaged in the study were milk production (L/day), lactation length (days), age at first calving (months), service per conception (number), post-partum oestrus (days), dry period (days), calving intervals (days), gestation length (days). All values relating to production and reproduction of $\mathrm{HF}$ and IG cows were expressed as Mean \pm SD. The statistical analyses were done using Statistical Package for the Social Science (SPSS), version16. Paired sample't' test was done to find out significant differences in production and reproduction parameters between $\mathrm{HF}$ and IG cows.

\section{Results}

\section{Milk yield}

The average milk yields of $\mathrm{HF}$ and IG cows were $7.64 \pm 1.74$ and $1.75 \pm 0.07 \mathrm{~L} / \mathrm{d} /$ cow respectively (Table 1). There was a significant difference $(p<0.01)$ in daily milk yield of HF and IG cows.

Lactation length

The average lactation length of $\mathrm{HF}$ and IG cows were $257.50 \pm 14.17$ and $210 \pm 20.73$ days respectively (Table1).

\section{Age at first calving}

The average age at first calving of $\mathrm{HF}$ and IG cows were $36.43 \pm 2.72$ and $40.07 \pm 0.83$ months respectively (Table 2 ). The age at first calving of IG was 4 months higher than HF cows. IG showed significantly higher age at first calving $(p<0.01)$ than that of $\mathrm{FH}$ cows.

\section{Service per conception}

In Table 2 the number of service per conception of $\mathrm{HF}$ and IG cows is presented. The average number of service per conception for $\mathrm{HF}$ and IG were $1.21 \pm 0.11$ and $1.14 \pm 0.04$ respectively.

Post-partum oestrus

The average Post-partum oestrus of HF and IG cows were $125.07 \pm 22.29$ and $157.88 \pm 9.93$ respectively (Table 2 ). Post-partum oestrus of IG cows was significantly higher $(p<0.05)$ than HF. Dry period

Average dry period of IG and HF cows were $170.96 \pm 7.40$ and $123.57 \pm 20.35$ respectively (Table 2). Significantly $(p<0.01)$ higher dry periods were found in IG cows than HF cows.

\section{Calving intervals}

In Table 2 the average calving intervals of $\mathrm{HF}$ and IG cows were $420.07 \pm 21.76$ and $446.82 \pm 10.33$ respectively. In these results calving intervals of IG cows were 26 days higher than HF cows.

Gestation Length

The average gestation period of $\mathrm{HF}$ and IG cows were $274 \pm 3.95$ and $276 \pm 3.31$ respectively (Table 2 ). The gestation period of HF and IG cows were almost similar where no significant $(p>0.05)$ difference was found. 


\section{Performance of Holstein Friesian crossbred and indigenous cow}

Table 1. Productive performance of Holstein Friesian Crossbred and Indigenous cows (Mean \pm SD).

\begin{tabular}{llccc}
\hline Parameter & HF Crossbred & Indigenous & p-value & Level of significance \\
\hline Daily Milk Yield (L/d/cow) & $7.64 \pm 1.74$ & $1.75 \pm 0.07$ & 0.002 & $* *$ \\
Lactation Length (days) & $257.50 \pm 14.17$ & $210 \pm 20.73$ & 0.004 & $* *$ \\
\hline
\end{tabular}

**Significant at $1 \%$ level $(p<0.01)$; *Significant at $5 \%$ level $(p<0.05) ; N S=$ nonsignificant

Table 2. Reproductive Performances of Holstein Friesian Crossbred and Indigenous Cows (Mean \pm SD).

\begin{tabular}{lllll}
\hline Parameter & Crossbred & Indigenous & p-value & $\begin{array}{c}\text { Level of } \\
\text { significance }\end{array}$ \\
\hline Age at first calving (months) & $36.43 \pm 2.72$ & $40.07 \pm 0.83$ & 0.008 & $* *$ \\
Service per conception (number) & $1.21 \pm 0.11$ & $1.14 \pm 0.04$ & 0.868 & NS \\
Post- partum oestrus (days) & $125.07 \pm 22.29$ & $157.88 \pm 9.93$ & 0.036 & $*$ \\
Dry period (days) & $123.57 \pm 20.35$ & $170.96 \pm 7.40$ & 0.005 & $* *$ \\
Calving intervals (days) & $420.07 \pm 21.76$ & $446.82 \pm 10.33$ & 0.001 & $* *$ \\
Gestation Length (days) & $274 \pm 3.95$ & $276 \pm 3.31$ & 0.079 & NS \\
\hline
\end{tabular}

$* *$ Significant at $1 \%$ level $(p<0.01)$; *Significant at $5 \%$ level $(p<0.05) ; N S=$ nonsignificant

\section{Discussion}

\section{Milk yield}

The milk yield of HF cows was significantly $(p<0.01)$ higher than the IG cows. From the result it shows that average daily milk yield of $\mathrm{HF}$ was 6 times higher than IG cows. This result is near to the findings of of Halim (1992) who showed that average milk yield of crossbreed dairy cows was 3.09 L/ d/cow. Similarly, Nahar et al. (1992) who reported that total lactation yield of Sindhi $x$ Local, Sahiwal $x$ Local, Jersey $x$ Local and Holstein $x$ Local were 949.10 \pm 196.00 , $470.40 \pm 242.00, \quad 1156.10 \pm 339.00 \quad$ and $1702.81 \pm 442.00$ litres, respectively.

\section{Lactation length}

A significant difference was found in lactation length $(p<0.01)$ between HF and IG cows. The average lactation of HF cows was 47 days higher than IG cows. The lactation length in the present study agrees with the findings of Hasan (1995), who revealed the average lactation period of Jersey, Holstein, Sahiwal and Sindhi crosses were 286, 272, 262 and 255 days, respectively. Khan (1991) reported that the average lactation period of Pabna, Sindhi cross and Sahiwal cross were 200, 251 and 282 days, respectively.

\section{Age at first calving}

The average age at first calving of $\mathrm{HF}$ and IG cows were $36.43 \pm 2.72$ and $40.07 \pm 0.83$ months respectively. The age at first calving of IG cows was 4 months higher than HF cows. IG showed significantly higher age at first calving $(p<0.01)$ than that of FH cows. Lahouse (1960) noticed that the age at first calving was 32 to 40 months for Friesian crossbred cows. Rokonuzzaman et al., (2009) found age at first calving of Holstein Friesian crossbred and indigenous cows as 34.12 \pm 3.78 and $40.48 \pm 4.54$ months respectively.

\section{Service per conception}

The average number of service per conception for $\mathrm{HF}$ and IG cows was statistically similar. No significant $(p>0.05)$ difference was found between HF and IG in number of service per conception. Shamsuddin (1995) found that 2.0 services required per conception in the village

cow herds of Mymensingh district. Jabbar and Ali (1988) studied the productive performance of indigenous and crossbred cows in Bangladesh and demonstrated the overall service per conception was $\mathbf{1 . 6 6}$ for crossbred and indigenous cows. 


\section{Post-partum oestrus period}

Post-partum oestrus of IG cows was significantly higher $(p<0.05)$ than HF cows. In the study, it is observed that post-partum oestrus period in IG was delayed 32 days more than HF cows. In the study of Ali et al. (2000) found that post-partum heat period of cross bred and indigenous cows were $109.59 \pm 26.87$ and $103.83 \pm 18.54$ days, respectively. Rokonuzzaman et al., (2009) conducted an experiment and reported that postpartum oestrus period of Holstein Friesian crossbred and indigenous cows were 86.48 \pm 23.67 and $121.2 \pm 52.90$ days respectively. The result of the present experiments nearly agrees with the findings of Rokonuzzaman et al., (2009). Nahar et al. (1989) reported that different breeds had a significant effect on ost-partum oestrus period. They found that ost-partum oestrus period in different breed groups ranged from $113.93 \pm 5.45$ to $150.71 \pm 4.42$ days.

\section{Dry period}

Dry period of HF cows was 47 days lower than IG cows which in turn increased lactation length of HF cows. Significantly $(p<0.05)$ higher dry periods were observed in IG cows than HF cows. The result is near to Nahar (1987) who found the dry periods of F1 Sindhi and Sahiwal cross were 145.9 and 127.2 days, respectively.

\section{Calving intervals}

Calving intervals were significantly $(p<0.01)$ lower in HF cows than that of IG cows. This result nearly agrees with the findings of Nahar (1987) who mentioned that the average calving interval of Sindhi cross, Jersey cross and Holstein crossbred cows were 452, 486 and 436 respectively. Rokunuzzaman (2006) concluded that there were significant differences $(p<0.01)$ among the calving interval of different types of dairy cows. Similarly, Hasan (1995) found that calving interval of Jersey cross, Sahiwal cross, Sindhi cross, Holstein cross were 499 \pm 87.4 , $488 \pm 61.4$, 491 \pm 99.4 , 515 \pm 103 days, respectively. Calving interval of different breeds might be influenced by genetic, environmental, feeding and managemental effects.

\section{Gestation Length}

There was no significant ( $p>0.05$ ) difference was found in gestation length. There was only 2 days difference in gestation period of HF and IG cows. The result agrees with Majid et al. (1995), who mentioned a non-significant variation in gestation period among different crossbreds. Similar result was also obtained by Rahman et al. (2009). They found a range of gestation period of 270-285 days and no significant variations was observed in gestation length among different breeds and crossbreds. Nahar et al. (1992) also reported that the gestation period of different crosses varied little from 280 days.

\section{Conclusion}

This study revealed that the performance of Holstein Friesian crossbred cows was better in terms of production and reproduction than that of indigenous cows. For the development of dairy production in Bangladesh, Holstein Friesian crossbred cows can be reared specially in the area where the bank of the river can be used as grazing land.

\section{References}

Alam MGS and Ghosh A (1988). Reproductive performance of cows: its relation to parity and season. Bangladesh Veterinary J ournal, 22: 51-61.

Bangladesh economic survey, (2013-2014). Economic advisory sub-section, Economic Section, Ministry of Finance, Government of Peoples' Republic of Bangladesh. Dhaka. 104-105.

Department of Livestock Services (DLS) 2014. Fisheries and livestock Ministry, Dhaka, Bangladesh.

Djemali M, Freeman AE and Berger PJ (1987). Reporting of dystocia scores and effects of dystocia on production, days open, and days dry from dairy herd Improvement data. Journal of Dairy Science, 70: 2127-2131.

FAOSTAT (2013). Food and Agricultural Organization, United Nation, statistics division.URL: http://faostat3.fao.org/browse/ Q/QA/E.

Ghosh A, Alam MGS, Pandit KK and Kamaruddin KM (1988). Seasonality of post partum 


\section{Performance of Holstein Friesian crossbred and indigenous cow}

reproductive performance at indigenous cows of Bangladesh. The Bangladesh Veterinarian, 5: 73-75.

Halim (1992). Comparative economic analysis of local and cross-bred dairy cows in a selected area of Dhaka district, Bangladesh. M.S. thesis, Dept. of Agricultural economics, Bangladesh Agricultural University, (BAU), Mymensingh.

Hasan MM (1995). Distribution pattern and some economic dairy characters of locals and crossbred cows in Mymensingh Sadar. M.S. Thesis, Department of Dairy Science, Bangladesh Agricultural University, Mymensingh.

I slam MA, Alam MK, Islam MN, Khan MA, Ekeberg D, Rukke EO, Vegarud GE (2014). Principal milk components in buffalo, Holstein Friesian Cross, Indigenous Cattle and Red Chittagong Cattle from Bangladesh. Asian Australasian Journal of Animal Science, 27: 886-897.

Jabbar MA and Ali SZ (2007). The limitations of cross breeding for improvement of cattle in Bangladesh. Oxford Agranian Studies, 17(1):29-56

Kaya I, Uzmay C, Kaya A, Akbas Y (2003). Comparative analysis of milk yield and reproductive traits of Holstein-Friesian cows born in turkey or imported from Italy and kept on farms under the Turkish-ANAFI project. Italian Journal of Animal Science, 2: 141-150.

Khan MAS, Amin MR, Howlider MAR and Hussain SM (1991). Successive reproductive and milk yield performance of dairy cows. Bangladesh Journal of Training and Development, 4: 31-38.

Lahouse A (1960). The effect of age at first calving on milk production. Dairy Science Abstracts, 24: 172.

Majid MA, NaharTN, Talukder Al and Rahman MA (1995). Factors affecting the reproductive efficiency of crossbred cows.
Bangladesh Journal of Livestock Research, 2: 18-22.

Nahar TN, Islam M and Hashath MA (1992). A comparative study on the performance of $\mathrm{F} 1$ crossbred cows under rural conditions. Asian Australasian Journal of Animal Science, 5: 435-338.

Nahar N, Mostafa KG and Amin MR (1987). Comparative study on the performance of F1 cross-bred cows. Bangladesh Journal of Animal Science, 18: 55-62.

Rahman MS, Ahmed M and Ahmed AR (1987). A comparative study on some productive and reproductive performance of dairy cows at Savar Dairy cattle improvement farm. Bangladesh Veterinary Journal, 21: 55-61.

Rahman MF, Islam MS, Hossain MA, Prodhan MA and Rahman A (2009). Reproductive patterns of different breeds of cows in Bangladesh. Bangladesh Journal of Livestock Research, 1: 19-24.

M. Rokonuzzaman, M. R. Hassan, S. Islam1 and S. Sultana (2009). Productive and reproductive performance of crossbred and ndigenous dairy cows under smallholder farming system, Journal of Bangladesh Agricultural University, 7(1): 69-72.

Saadullah M (2001). Smallholder Dairy Production and Marketing in Bangladesh. Paper presented at South-South Workshop on Smallholder Dairy Production and Marketing. NDDB-ILBS, 13-16, March. Ahmedabad, India.

Shamsuddin M, Ahmed JU, Alam MGS and Modak PC (1987). Effect of age of semen on conception rate under farm condition. Bangladesh Veterinary Journal, 21: 51-58.

Shamsuddin M (1995). Fertility trend and status of estrus detection in the bovine under the farm conditions in Bangladesh. Bangladesh Journal of Veterinary Medicine, 2: 9-16.

Statistical Package for the Social Science (SPSS) 16. Released (2007). SPSS for Windows, Version 16.0. Chicago, SPSS Inc. 